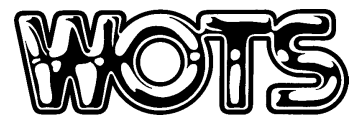

\title{
Archaeological Site and Reservoir Shoreline Stabilization Using Wetland Plants and Bioengineering, Rice Reservoir, Wisconsin
}

\section{by Cathy J. Wendt and Hollis H. Allen}

PURPOSE. This technical note describes a case study in which wetland plants and bioengineering treatments were used to protect an archeological site on an eroded reservoir shoreline and to stabilize the shoreline from further erosion. The site is called the Robinson Site and is located on Rice Reservoir in northern Wisconsin, about $26 \mathrm{~km}$ (16 miles) southeast of Rhinelander.

\section{BACKGROUND AND SITE} DESCRIPTION: The Robinson archaeological site 47Li-1/ On-27 is located on a high, roughly rectangular peninsula, locally known as Robinson's Point, which extends into the main body of Rice Reservoir (Lake Nokomis). A narrow neck of land at the southeast corner of the peninsula connects to the adjacent upland (Figure 1). Prior to the construction of Rice Reservoir, Robinson's Point lay within a broad meander of Little Rice Creek. The site is one of the largest prehistoric sites in the region and contains human remains as well as habitation debris. The project

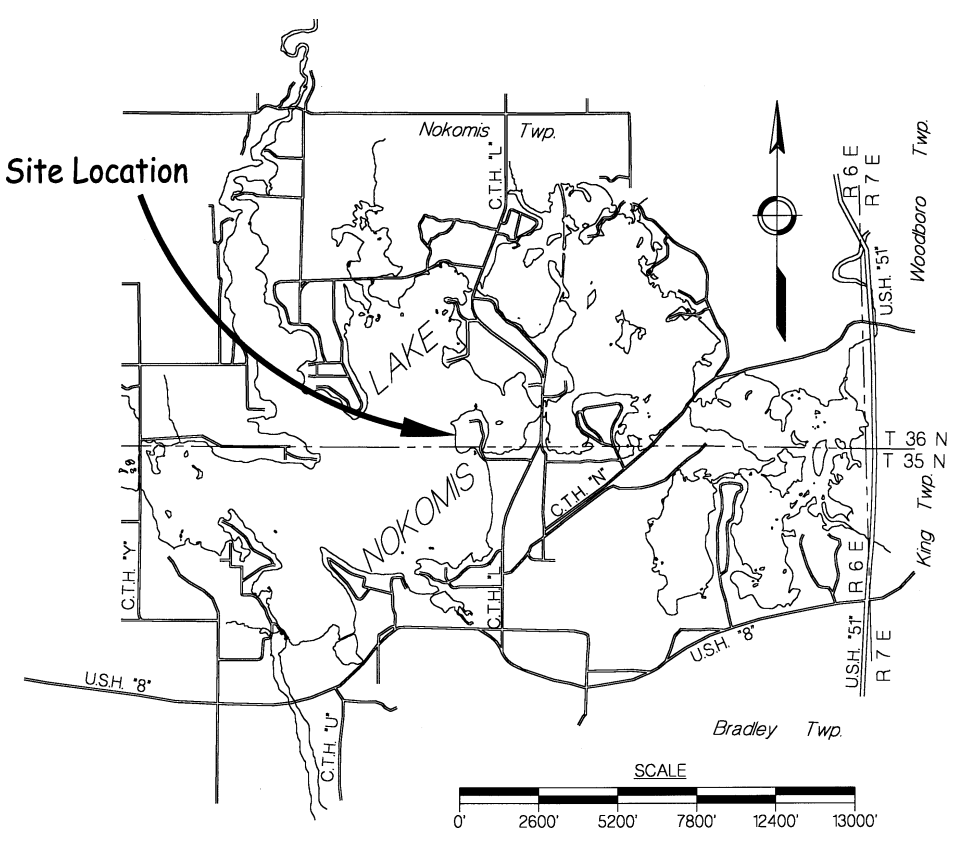

Figure 1. Location of 47Li-1/On-27 (Robinson Site) area is 230 lin $\mathrm{m}$ (750 lin ft) on the west side of the archaeological site extending north from the southwest corner of the peninsula.

The project was divided into three zones defined by the severity of erosion and associated measures used to protect the bank (Figure 2). Zone 2 was the most severely eroded and contained a partially exposed burial mound. Portions of each zone were included in a workshop held in April 1999. The purpose of the workshop was to learn bioengineering techniques and share expertise with State and local agencies and with private entities. A description of each zone prior to construction follows. 


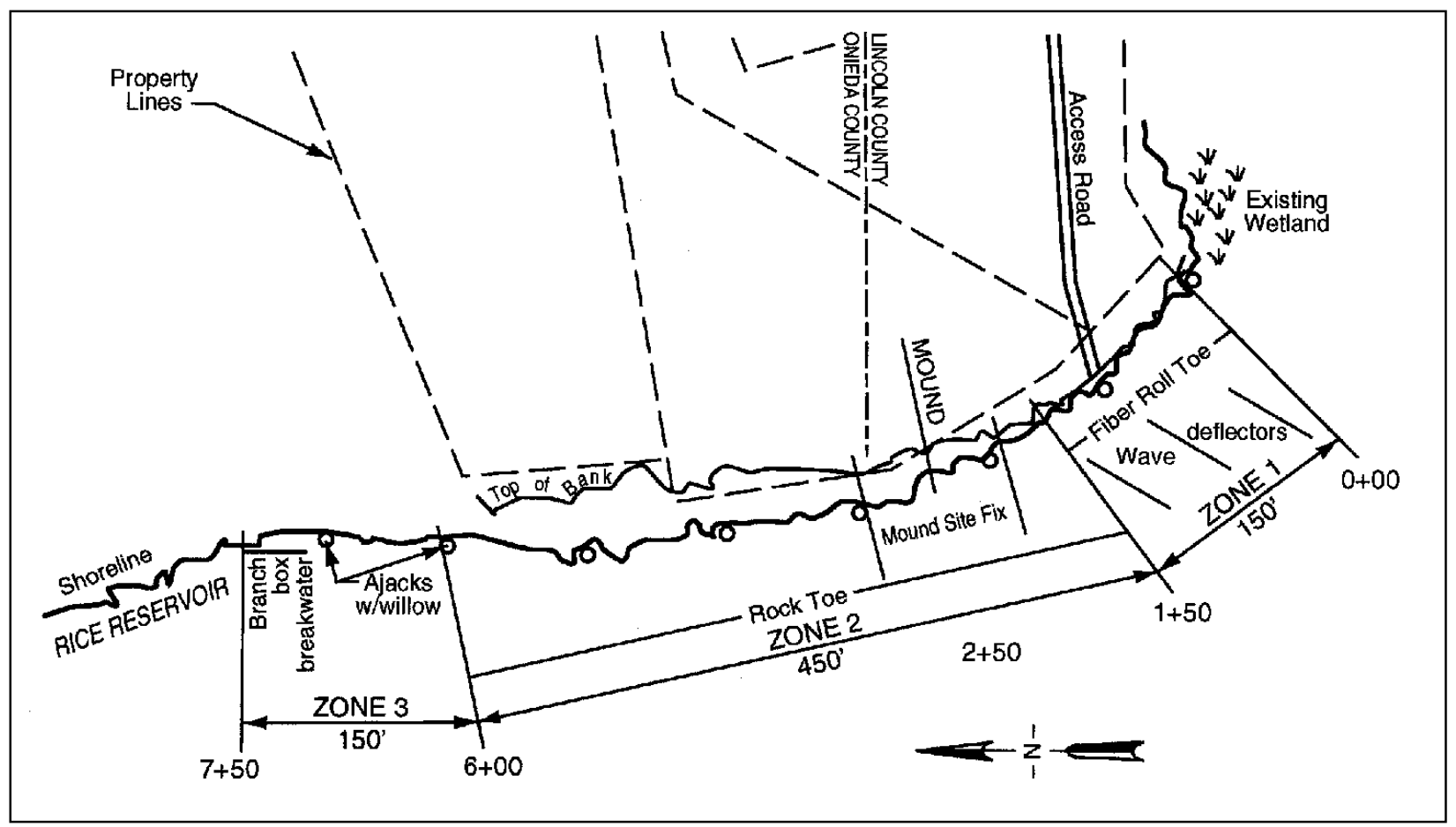

Figure 2. Zones of eroded shoreline and installed measures

- Zone 1 - The southern 45-m (150-ft) section varied in bank height from 0 to $4 \mathrm{~m}$ (0 to $12 \mathrm{ft})$. A natural wetland exists around the point at the south end. This zone had vertical, lower banks that required less protection.

- Zone 2 - The middle 14-m (450- ft) section was the most severely eroded. Bank heights varied from $4 \mathrm{~m}$ to more than $9 \mathrm{~m}(12$ to $30 \mathrm{ft})$ with an average slope of 1.5(h):1(v). This zone required installation of a hard toe and stabilization of the face of the bank.

- Zone 3 - The northern 45-m (150-ft) section had the least amount of active erosion. The face of the bank in this area was fully vegetated with red and white pine, white birch, oak, aspen, shrubs, and herbaceous plants. Bank height varied from 0 to $6 \mathrm{~m}(0$ to $20 \mathrm{ft})$ and the only erosion evident was an undercut lip at the toe of the bank. This zone required methods where no disturbance of the bank would occur. Protection was added at the toe to attenuate wave action that threatened the semi-stable area.

The goal of the project was to protect a valuable cultural resource site from further erosion. The primary objective was to protect the site in the most cost-effective way. However, multiple secondary objectives were also an important part of the project and these objectives drove the cost of the project up. Secondary objectives were to:

- Protect the site without further disturbance to an already exposed burial mound. 
- Use bioengineering techniques that would enhance reservoir shoreline habitat. The major constraints were not being able to dig into the original bank or encroach onto the bed of the reservoir as prohibited by Section 1.11, 30.12(3) Wisconsin Statutes.

ZONE 1 - IMPLEMENTED PLAN: A combination of two techniques was used on this 45-m (150-ft) section. These techniques were installed during a workshop in April 1999.

- Fiber rolls (geotextile rolls made from coconut husks) were installed at the toe of the bank.

- Wave deflectors made from large dead trees were partially buried, anchored, and placed 30 deg perpendicular to the bank to encourage expansion of the natural wetland.

Site Preparation. No bank disturbance was required. One leaning tree on the point was cut, but the tipped root mass was left.

Fiber Roll Installation. Four 30-cm- (12-in.-) diameter and three 40-cm- (16-in.-) diameter fiber rolls were installed. Their configuration varied with the shape and height of the bank. A single $\quad 30$-cm- (12-in.-) diameter roll was used where the bank was lowest and was positioned to "fit" under the lip of the existing undercut bank (Figure 3). As the height of the bank increased, fiber rolls were placed two and three high, resulting in a tiered structure. The fiber rolls were anchored in place with 1- to $1.2-\mathrm{m}$ - (3- to 4-ft-) long wooden construction stakes made of 2 by 4's cut diagonally to

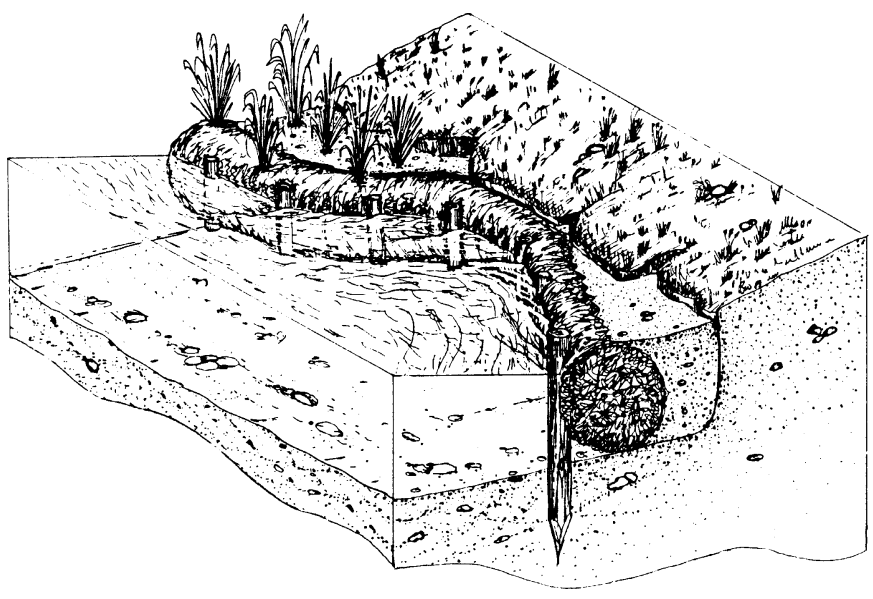

Figure 3. Fiber roll toe form a longitudinal taper. Native rushes and sedges including Juncus spp. and Scirpus spp. were harvested from a nearby wetland and transplanted into the bottom fiber rolls after installation. A pack of slow-release fertilizer was placed at the base of each plant in the fiber rolls. Voids between the bank and the fiber rolls were filled with topsoil and planted with willow cuttings and pre-rooted willows provided by the U.S. Forest Service (USFS) North Central Forest Experiment Station. Several species and clones (USFS stock), being grown for restoration projects, were used throughout this project for field evaluation. A row of dormant native willow cuttings was planted in front of the exposed, tipped root mass to attenuate wave action and prevent additional scouring from under the roots. Additional willow cuttings (USFS stock) were placed between the fiber rolls on July 11, 2000.

Wave Deflector Installation. Three to four large trees were stacked with alternating butt ends together (Figure 4) at approximately $30 \mathrm{deg}$ perpendicular to the shoreline. The trees were 


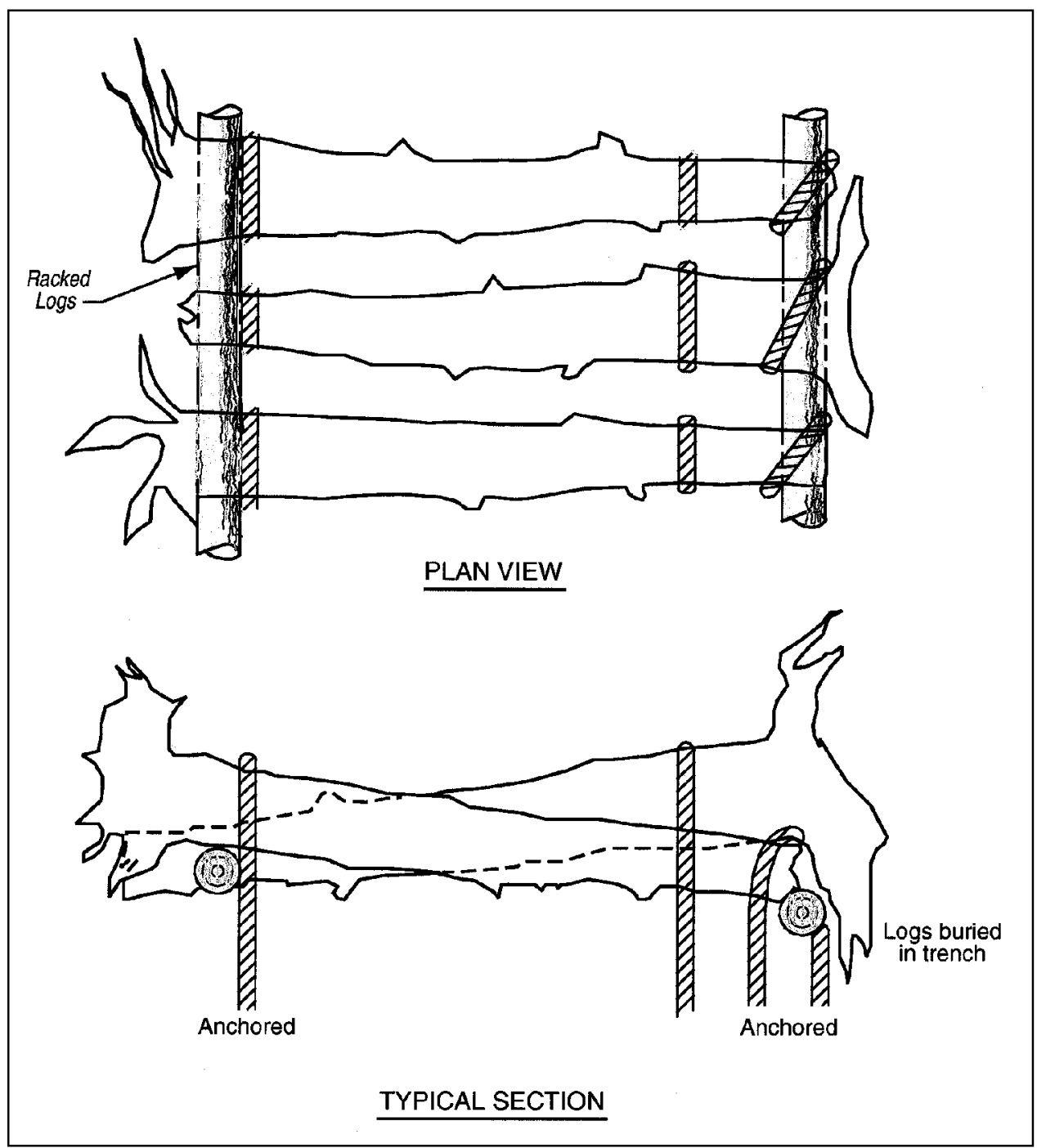

Figure 4. Anchored log wave deflector

placed on top of two pieces of 25- to 30-cm- (10- to 12-in.-) diameter red pine partially buried in the reservoir bottom and lying perpendicular to the trees. The trees were cabled in place using Duckbill ${ }^{\circledR}$ anchors. The wave deflectors were placed to block waves from northerly and northwesterly winds. The Duckbill ${ }^{\circledR}$ anchors were driven into the reservoir bottom, leaving only the portion of the cable connecting the trees exposed.

ZONE 2 - IMPLEMENTED PLAN: A rock toe was installed along this section. Installation began on March 5, 1999 and continued until March 29, when the available supply of rock was depleted. Work resumed when additional rocks were obtained. The rock toe was completed September 13, 1999. There were two variations of the rock toe method. One method was employed at the critical area, 30 lin $\mathrm{m}$ (100 lin $\mathrm{ft}$ ) centered on the burial mound (Figure 5), and the other method was utilized in the remaining $107 \mathrm{~m}(350 \mathrm{ft})$ of the zone (Figure 6). The distance the rock toe was placed from the original toe of the bank varied from 0 to $3.4 \mathrm{~m}$ ( 0 to $11 \mathrm{ft}$ ). This distance was based on the slope necessary to provide stability without cutting back into the top of the bank. Within the critical $30-\mathrm{m}(100-\mathrm{ft})$ area, a vegetated geogrid was 
Zone 2 - Mound Fix

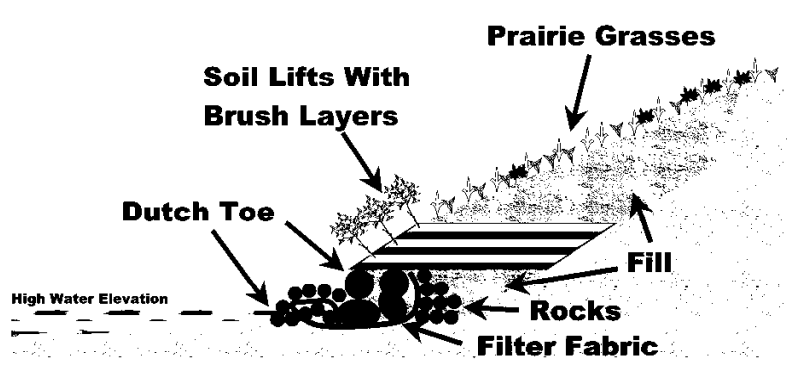

Figure 5. Mound site fix
Zone 2 - Fix Away From Mound

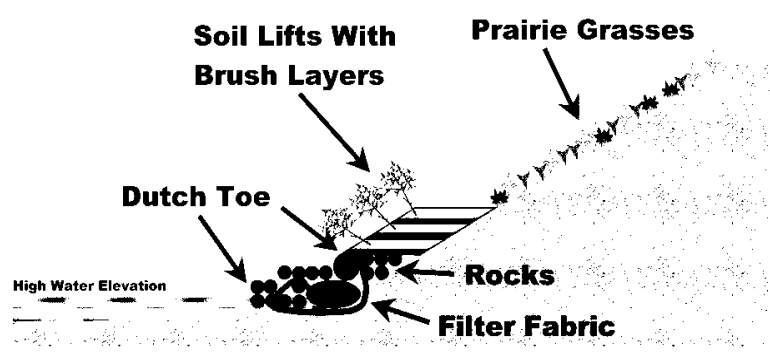

Figure 6. Fix away from mound area

constructed above the rock toe using four encapsulated soil lifts. Throughout the remaining $107 \mathrm{~m} \mathrm{(350} \mathrm{ft),} \mathrm{zero} \mathrm{to} \mathrm{three} \mathrm{lifts} \mathrm{were} \mathrm{used} \mathrm{as} \mathrm{deemed} \mathrm{necessary.} \mathrm{The} \mathrm{top} \mathrm{bank} \mathrm{treatment} \mathrm{also}$ varied, with a more extensive design employed at the critical 30-m (100-ft) area.

Site Preparation. Overhanging trees were removed from the top of the bank. The requisite distances from the existing toe of the bank were measured and marked with paint. A level 1.2-m(4-ft-) wide trench was dug along the paint line to $60 \mathrm{~cm}(2 \mathrm{ft})$ below the high water elevation (HWE). A silt fence was installed prior to any bank disturbance.

Rock Toe Installation. The rocks used for armoring at the toe were 50 to $90 \mathrm{~cm}$ (18 to $36 \mathrm{in}$.) in diameter and were stacked to a height of at least $60 \mathrm{~cm}(2 \mathrm{ft})$ above the HWE. In the critical area $(30 \mathrm{~m}(100 \mathrm{ft})$ centered on the exposed burial mound) they were placed two rows deep. The remaining $107 \mathrm{~m}(350 \mathrm{ft})$ employed the same method, but the large rocks were only one row deep. The method used filter fabric and smaller rock in combination with the large rocks, resulting in the "Dutch Toe" treatment shown in Figures 5 and 6. The rocks were placed at an angle of at least 10 deg from the vertical into the embankment to provide a transition into the slope. The rock toe was constructed following these steps:

- The trench was lined with a nonwoven $4.5-\mathrm{m}-(15-\mathrm{ft}-)$ wide geotextile. The geotextile was placed so that 1.2 to $1.5 \mathrm{~m}$ (4 to $5 \mathrm{ft}$ ) of excess fabric was left on either side of the trench.

- A row of smaller rocks was placed on the geotextile along the reservoir side of the trench. The geotextile was pulled back toward the bank encapsulating the row of small rocks. Construction stakes (made from 2 by 4 's) were used to secure the geotextile.

- The large rocks were placed on the geotextile, in the trench, just behind the encapsulated roll of smaller rocks. The excess geotextile on the landward side of the trench was pulled up behind the large rocks.

- Smaller rock was placed landward of the geotextile to the height of the large rocks.

- Smaller rock was placed at the base of the large rocks on the reservoir side to cover the exposed filter fabric. 
- The area between the small rocks and the existing toe of the bank was filled with sand fill and compacted, leaving a level shelf from the rock toe back to the bank.

Vegetated Geogrid Installation. A vegetated geogrid consisting of brush layers and encapsulated soil lifts was installed on the slope behind the rock toe. Typically, the brush layers consisted of brush cut during dormancy and installed soon after harvesting or kept in cold storage until used. However, an alternative method using pre-rooted brush was used in parts of the project. The method involved rooting dormant brush in 1.2-m- (4-ft-) wide coir mats placed in "brush layer boxes." The boxes were initiated in a greenhouse, then the brush layer mats were removed and transferred to the field where they were planted as growing brush layers. This provided a much longer planting window, since the mats could be installed anytime during the growing season. A geotextile and a geogrid were combined in the soil lifts. Polyjute ${ }^{\circledR}$, an openweave geotextile, was used as the inside layer to contain fines while allowing roots to penetrate and Tensar $\AA$, a synthetic geogrid, was used as the outside layer to ensure greater internal strength of the slope. A jig and batterboard system resulted in uniform 30-cm- (1-ft-) high lifts. The vegetated geogrid was constructed following these steps:

- The first brush layer was installed on the level top of soil behind the rock toe. It consisted of dormant native willow and dogwood cuttings. The cuttings were a minimum of $90 \mathrm{~cm}(3 \mathrm{ft})$ long with a $1.2-$ to $2.5-\mathrm{cm}(1 / 2-$ to 2 -in.) diameter, and were placed in a random, crosswise pattern with the tips protruding slightly beyond the face of the slope.

- The brush layer was then covered with soil.

- The distance from the outside edge of the new bank toe back to the original bank was measured. The Polyjute ${ }^{\circledR}$ and Tensar ${ }^{\circledR}$ synthetics were cut slightly longer than twice the measured distance.

- The synthetic materials were placed on the brush layer and as far back toward the bank as

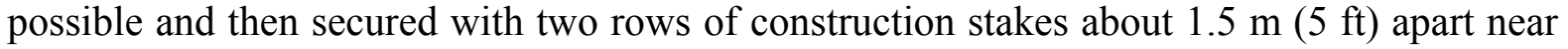
the back of the layer. The excess was temporarily draped down the front over the batterboard and rock toe.

- Native fill material obtained from a nearby pit was placed on top of the geotextiles. The soil was compacted in 15-cm- (6-in.) lifts, and filled to the top of the batterboard, resulting in a 30-cm- (12-in.) lift.

- The fabric was then pulled up and over the fill and staked in place at the rear.

This process was then repeated for each layer. The growing brush layers were used at the critical area, rather than dormant unrooted cuttings.

Top Bank Treatment. Two variations were utilized. The critical area near the mound was filled above the vegetated geogrid to the top of the bank (Figure 5). The area was then hydroseeded with prairie grasses (Elymus canadensis, Andropogon gerardi, Schizachyrium scoparium, Bouteloua curtipendula, and Sorghastrum nutans) and covered with an Excelsior ${ }^{\circledR}$ 
erosion control blanket. The amount of fill was gradually reduced as the distance from the mound increased, thereby blending it into the previously existing bank configuration as illustrated in Figure 6. Where it was not already vegetated, the bank away from the mound area was hydroseeded with the same species of prairie grasses as listed above.

ZONE 3 - IMPLEMENTED PLAN: Two methods of protecting the toe without disturbing the upper bank were used in this section. They were installed during the April 1999 workshop.

- A 15-m (50-ft) branchbox breakwater was installed at the north end of the section.

- A-Jacks ${ }^{\circledR}$ (concrete structures that are interlocking) and Fibredam ${ }^{\circledR}$ (geotechnical fabric consisting of a curled matrix of synthetic fibers) were placed at the toe of the bank in the remaining $30 \mathrm{~m}(100 \mathrm{ft})$ of the section.

Branchbox Installation. The branchbox breakwater was built from cedar posts and brush during the April workshop. The breakwater is designed to be a temporary structure that diminishes wave energy while plants establish (Figure 7). The breakwater was positioned $4.5 \mathrm{~m}$ $(15 \mathrm{ft}$ ) out from the bank (the maximum distance Wisconsin DNR would allow) with the ends bending back in toward the toe of the bank. The ideal distance for the breakwater would have been $9.0 \mathrm{~m}(30 \mathrm{ft})$ out from the bank. The branchbox breakwater will be maintained until shoreline stabilization occurs and will then be removed.

The branchbox breakwater was constructed in the following sequence:

- Poles (2.4 m (8 ft) long) were placed vertically in the lake bottom, spaced $60 \mathrm{~cm}(2 \mathrm{ft})$ apart, in two rows

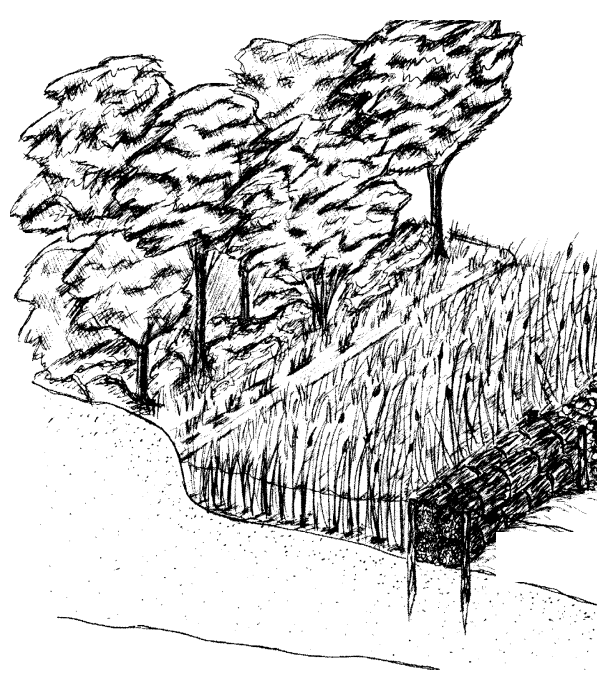

Figure 7. Branchbox breakwater lakeward of protected wetland plants $60 \mathrm{~cm}(2 \mathrm{ft})$ apart. The poles were initially augered in 60 to $90 \mathrm{~cm}(2$ to $3 \mathrm{ft})$ deep. Branches from dead and live materials were placed within the rows of poles to $30 \mathrm{~cm}(1 \mathrm{ft})$ from the top of the poles. The materials were graded, with diameters varying from fine tips to a maximum 5-cm (2-in.) diameter. The branches were primarily live alder and willow brush and placed with alternating butt ends and tips to allow maximum compaction.

- Stainless cable (1.6 mm (1/16 in.)) was wrapped around the poles and secured to the outside

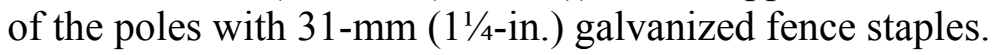

- The poles were then driven down firmly, with a vibrator head mounted on an excavator. Each pole was driven down only a few centimeters or inches at a time to prevent the cable from breaking. The process was repeated going back and forth along the breakwater until the brush

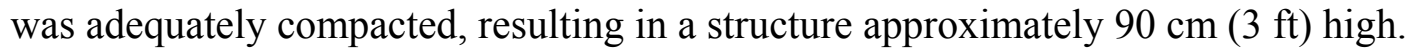


- Emergent aquatic vegetation purchased from a nursery (Iris versicolor, Acorus calamus, Scirpus fluviatilis, Scirpus cyperinus and Juncus effusus) was planted behind the breakwater. Transplants from a nearby wetland were planted in front of the breakwater.

A-Jacks ${ }^{\circledR}$ Installation. The A-Jacks ${ }^{\circledR}$ were installed during the April workshop. They were placed in rows so that each $A-J a c k s \circledR$ unit interlocked within each row and with the units in adjacent rows (Figure 8). Each A-Jacks ${ }^{\circledR}$ unit, when installed, has three 60-cm (24-in.) axes forming six $30-\mathrm{cm}\left(12\right.$-in.) legs. The lowest rows of A-Jacks ${ }^{\circledR}$ were trenched in close to the base of the bank. Fibredam ${ }^{\circledR}$ was placed between the rows and in the crevices to reduce soil movement and encourage root growth through the AJacks ${ }^{\circledR}$. Live native willow and dogwood cuttings were jetted into the structures in April. Pre-rooted willows (USFS stock) were planted between the A-Jacks ${ }^{\circledR}$ and the toe of the bank in mid-August. The A-Jacks ${ }^{\circledR}$ were backfilled in September with a soil/rock mixture.

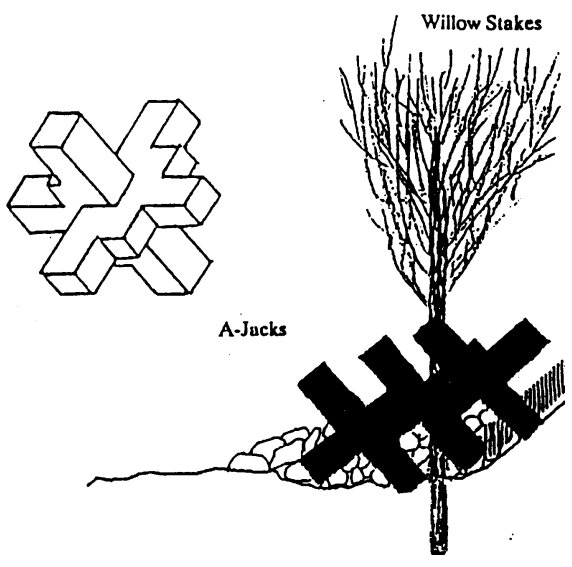

Figure 8. A-Jacks $®$ toe

PERFORMANCE: Visual observation, photo documentation, and/or a defined sampling program (depending on the particular installation for which the monitoring was being done) measured project performance. Nearly 1 year after completing this project, most of the stabilization measures appeared to be functioning satisfactorily.

In summary, the Zone 1 fiber rolls are functioning as anticipated but the wave deflectors failed to remain in place. The Zone 2 rock toe with vegetated geogrid has encountered a few isolated erosion problems but is experiencing tremendous brush growth. No visual evidence of the fall 1999 hydroseeding on the upper bank was apparent by mid-July 2000 and the area was reseeded on July 26. Germination was observed on a site visit on September 6, presumably of the July hydroseeding. In Zone 3, the branchbox breakwater is providing limited habitat but, because of its proximity to the shore, the breakwater is not fully functional. If it had been allowed to be placed farther offshore, the breakwater would have protected more area and would have supported more emergent aquatic plants shoreward of it. The Zone 3 vegetated A-Jacks ${ }^{\circledR}$ remain as placed and support abundant vegetation.

Zone 1 Fiber Roll Performance. In Zone 1, the fiber rolls have remained intact (Figure 9) with an added benefit of providing wildlife habitat. Burrowing animals, primarily rabbits, excavated and inhabited small

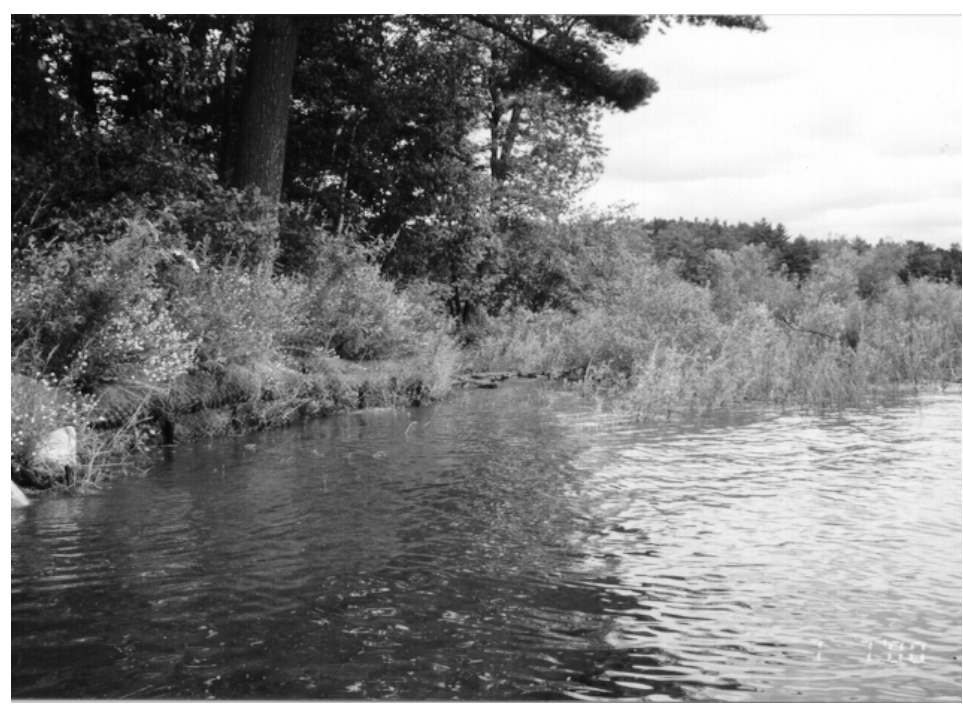

Figure 9. Zone 1, July 7, 2000 
openings behind the fiber rolls. These openings do not seem to be compromising the integrity of the structure. The rabbits browsed much of the willow over winter that had been planted as cuttings behind and between the fiber rolls. Despite the browsing, the willow resprouted. Of the 20 rooted willows (USFS stock) that were planted, 10 have survived.

Juncus spp.and Scirpus spp. planted directly in the fiber rolls suffered high mortality with only 10 percent of the original plants remaining on August 11. However, the fiber rolls are becoming vegetated by native volunteer species.

The row of native willow cuttings (Salix lucida) planted in front of the tipped root mass is surviving and functioning as a wave energy dissipater despite heavy predation from insects including willow sawfly (Nematus fulvicrus) and imported willow leaf beetle (Plagiodera versicolora).

Zone 1 Wave Deflector Performance. The wave deflectors failed within 5 months of installation. The precise cause of the failure was not documented or observed, but it appears that at a partial drawdown level, the wave action undermined the bottom crosspieces. When the water level again rose, it apparently floated the loosened crosspieces away, allowing the large trees they supported to buoy up and down with the waves, thereby loosening the anchoring system. The wave deflectors were removed entirely after the anchoring system failed.

Zone 2 Rock Toe Performance. The rock toe has performed as expected for the majority of the zone (Figure 10). Soon after completion, however, the reservoir level rose and a void was created behind the large rocks, causing 1.5 lin $\mathrm{m}$ ( $5 \mathrm{lin} \mathrm{ft})$ of soil lifts to collapse. Filling this area with small rock repaired the void and no further erosion has occurred in this area.

Additional smaller areas (1-2 $\mathrm{m}^{3}$ or 11-22 $\mathrm{ft}^{2}$ each) have also washed out, but no major problems seem to have been created by these voids. As a preventative measure, these new voids could be filled, but the voids seem to have limited themselves and our intent is to monitor them to see if they will be "self-healing." All of the voids are located away from the mound. It appears that the reduced level of armoring in the fix away from the mound may be contributing to these minor failures. No failures have occurred in the mound fix area.

Zone 2 Vegetated Geogrid Performance. Two separate methods were utilized to determine the performance of the brush layers in the vegetated geogrid. The "transect method" was used for species comparability and the "quadrat method" was used to determine overall vegetative coverage.

The transect method determined the survivability of the woody species by measuring 100 percent of the brush layers along transects. Survivability was determined by dividing the living stem occupation along the transect by the linear distance of materials originally planted. Each of the five layers was mapped (Figure 11) according to the species originally planted in the geogrid. Planting dates and harvesting dates were recorded. Portions of each brush layer consisted of different species (some were pre-grown in brush layer mats and some were installed as dormant cuttings). The species pre-grown in the brush layer mats were carefully monitored so valid comparisons between species could be made. The dormant cuttings were not differentiated by species but were intentionally mixed to increase the brush layer's chance of survival. Five 


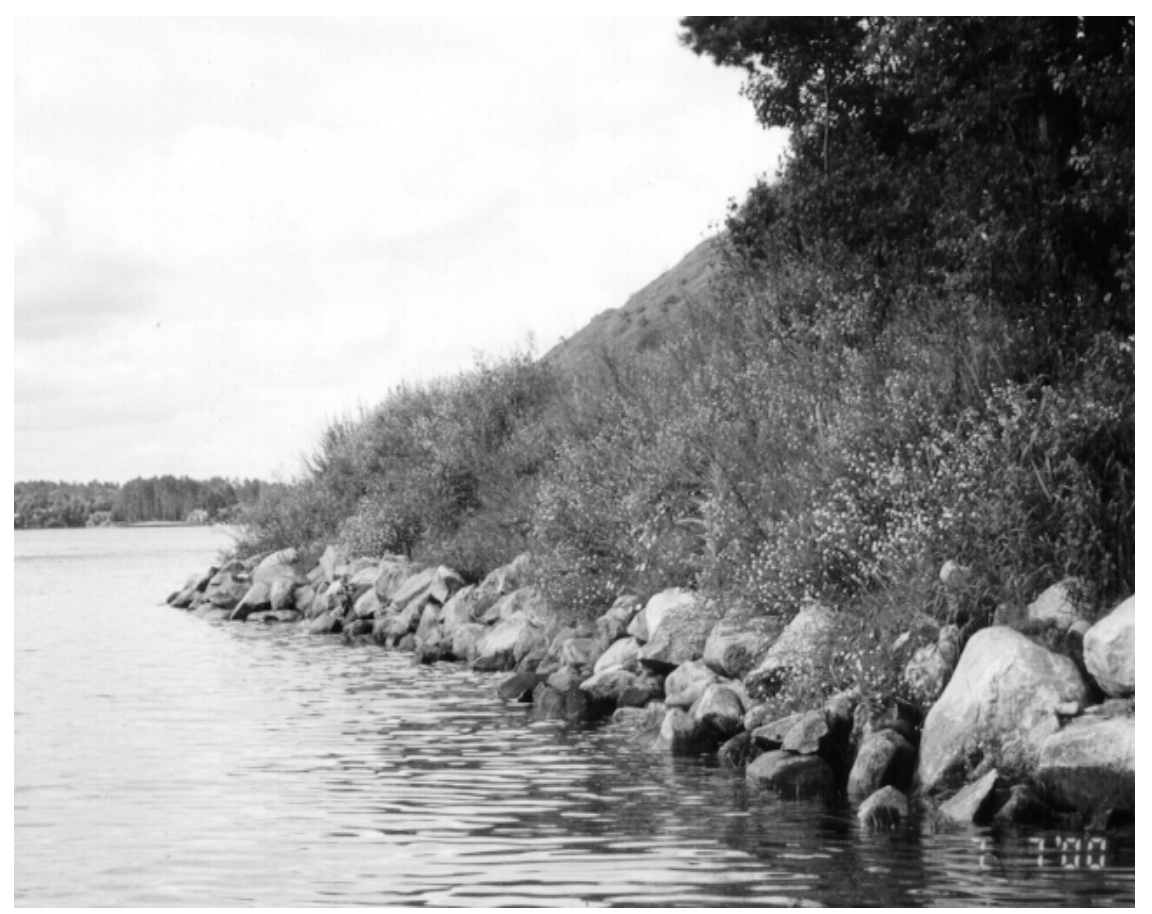

Figure 10. Zone 2, July 7, 2000

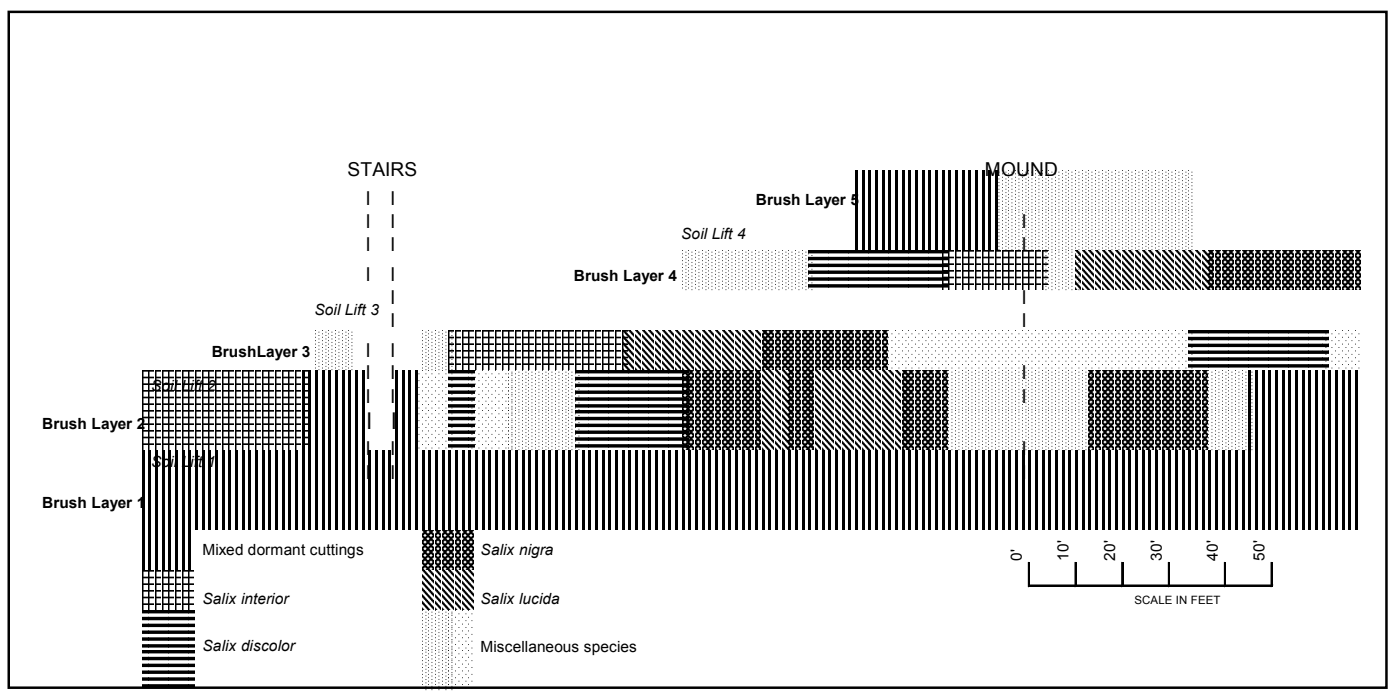

Figure 11. Diagram of brush locations in the geogrid

species of willow and one dogwood, Cornus stolonifera, were harvested locally and used in both variations in approximately the same proportions. This provided a means to compare the two planting techniques. Comparing only these six species, the pre-grown brush layer mats resulted in a 41.5-percent overall survival rate, slightly less than the 47-percent survival rate for the same species planted as dormant cuttings. 
Of the 85 pre-grown brush layer mats, 73 contained the six native species. The placement of the mats on the bank was designed to test survivability of these species (Figure 12) under differing conditions within the site. Cornus stolonifera was not included in the comparison since an adequate amount of material could not be located. One native willow species, Salix rigida, performed poorly in the greenhouse and was also eliminated from the comparison. The 19 mats containing these two species plus 12 mats containing USFS stock are designated as miscellaneous species on the layout map (Figure 11) and were used to fill in the remaining areas among the four species being tested. The remaining four species demonstrated no apparent advantage or disadvantage to placement on the bank.

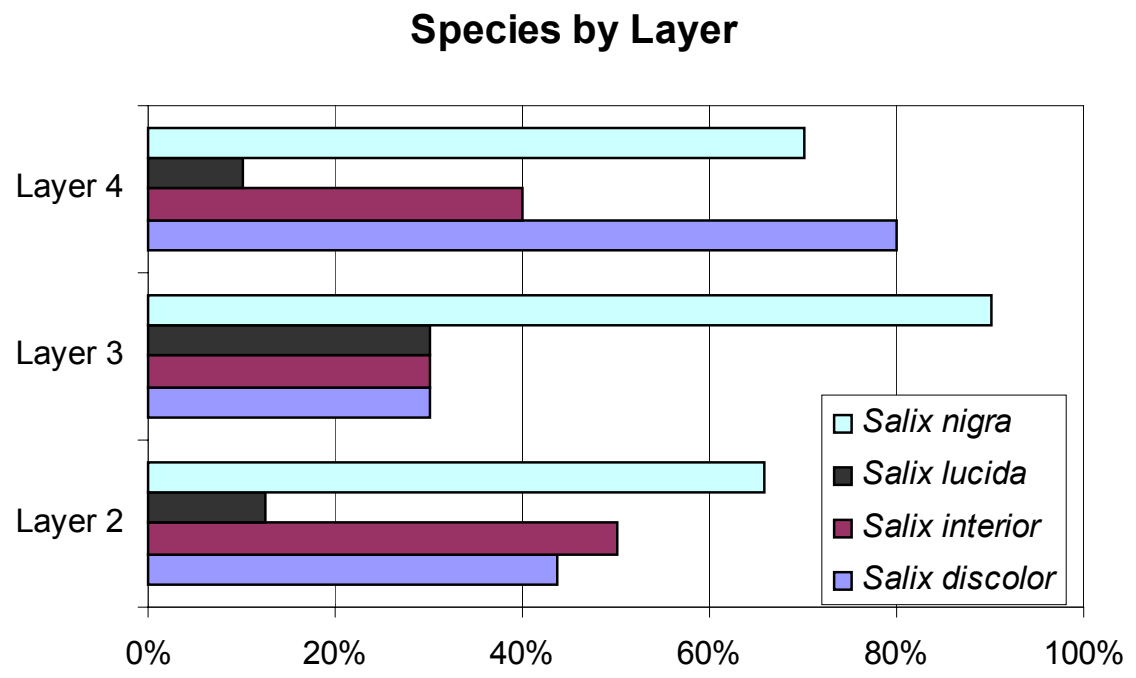

Figure 12. Plant survival by vegetative-geogrid height location by layer

The transect method revealed a steady increase in the coverage for each pre-grown mat during the four testing periods from July 14, 1999 to July 7, 2000, with the exception of three mats (Figure 13). For one mat (Cornus stolonifera), coverage dropped by 20 percent between May 17, 2000 and July 7, 2000. The other mats were Salix rigida, which were already doing poorly in the greenhouse. Some mats showed increases as high as 60-80 percent, with an average increase of 23-percent coverage between July 14, 1999 and July 7, 2000. The species with the highest survival percentages were Salix eriocephala (90.0 percent) and Salix purpurea (90.1 percent) both from USFS stock. The native locally harvested species with the highest percentages were Cornus stolonifera (72.8 percent) and Salix nigra (72.7 percent). Salix lucida and Salix rigida had the lowest survival (17.7 and 16.5 percent, respectively). The overall survival rate of all pregrown brush layer mats was 46.2 percent. 


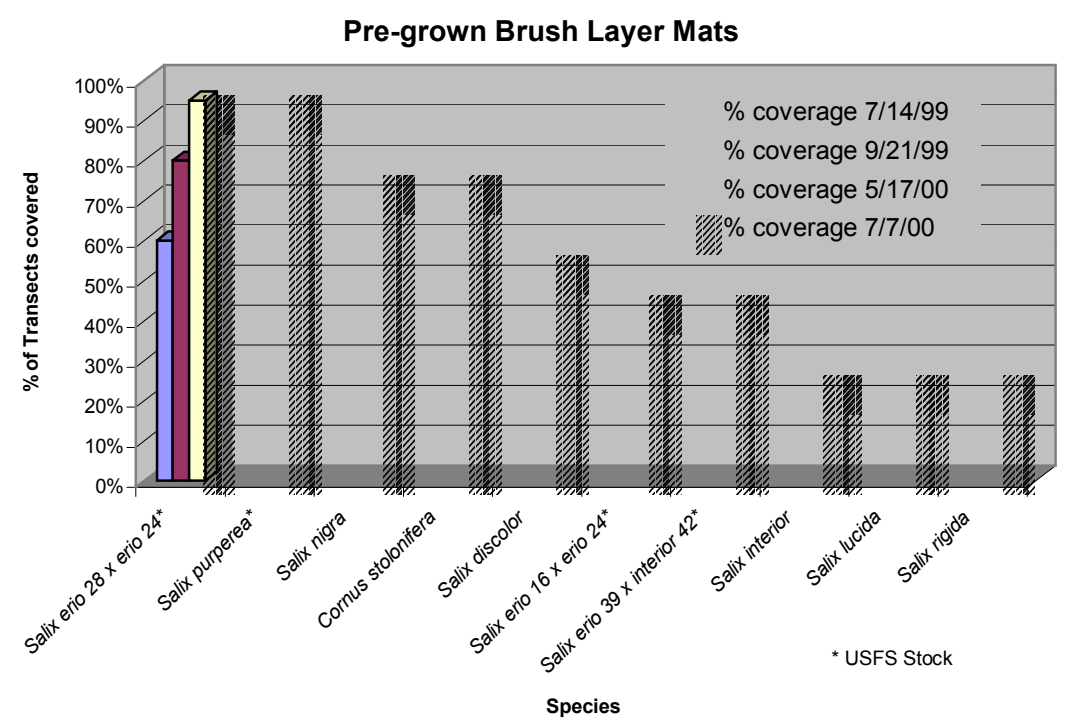

Figure 13. Performance (percent coverage) of brush layer mats by species

The second method utilized to determine the performance of the brush layers in the vegetated geogrid was the quadrat method. This method utilized a $1-\mathrm{m}^{2}\left(10.8-\mathrm{ft}^{2}\right)$ quadrat placed on a random $3.05-\mathrm{m}(10-\mathrm{ft})$ interval grid. The grid was established by initially looking at the second hand of a watch, with the number of seconds at that moment indicating the number of feet from a fixed point that would become the starting point of the grid. From that starting point, $3.05-\mathrm{m}$ $(10-\mathrm{ft})$ marks were placed along the base of the bank and from each of these $3.05-\mathrm{m}(10-\mathrm{ft})$ marks, a random quadrat was placed vertically up the bank with the second hand of the watch again determining its placement. This method was used to determine vegetative coverage including herbaceous plants.

The quadrat method reported an overall vegetative coverage of 41.0 percent. This value, which is lower than the 46.2 percent brush layer survival determined by the transect method, reflects the area between brush layers that wasn't planted, but instead relied on naturally inhabiting "volunteer" vegetation. Over 25 species were identified and ranked by abundance. The contribution of volunteer vegetation was substantial, with 65.5 percent of the area being covered by plants other than the woody species in the brush layers. Whether this is due to a more habitable environment being created by the brush layers or whether this would be a normal habitation rate for the reclaimed area cannot be determined from this study. Only 19.9 percent of the total area had overlapping coverage of Salix/Cornus species and herbaceous growth and only 21.1 percent of the total area was Salix/Cornus alone. The no-growth area (bare ground + Tensar ${ }^{\circledR}$ ) averaged 13.4 percent for the bank.

It should be noted that the quadrat methodology in this study may have injected some bias into the results. Since only one quadrat was placed every $3.05 \mathrm{~m}$ (10 lin ft) of bank, some areas were not represented as well as other areas. The bottom (first) layer covered a much longer linear distance than the top (fifth) layer. The north and south sections of the bank only had two brush layers, which resulted in these layers being tested more often. The northern end of the first layer 
had comparatively little willow growth. When these areas were tested, only one possible quadrat placement on the bank existed, compared with three to four possibilities on the remainder of the bank. This one quadrat placement carried the same weight in the study as in the areas with three or four possibilities (only one placement is used every $3.05 \mathrm{~m}(10 \mathrm{ft}$ ). The linear method portrays the brush layer coverage more accurately, since each individual mat is evaluated, although the method is more time-consuming. In this study, the linear method is very important since the performance of individual species is an important aspect.

It was apparent during data collection that a future factor to be considered will be insect invasion. A field investigation by USFS personnel revealed several species of insect (larvae and mature) having an impact on certain species of willow. Species identified include the imported willow leaf beetle, willow sawfly, twin-spotted sphinx (Smerinthus jamaicensis), and the willow redgall sawfly (Pontania proxima). Aphids were also reported, but the exact genus was not determined. Certain mats were heavily infested with the imported willow leaf beetle beginning in mid-July (after the last evaluation). A mid-August investigation indicated that the beetles probably have not permanently damaged the willow, but some of the willow does appear weakened - leaves are browning and some stems are drooping.

Zone 2 Top Bank Treatment Performance. A quadrat on a random grid was used on July 19, 2000 to determine a stem count for the hydroseeded area of Zone 2. An average total stem count of $32 \mathrm{stems} / \mathrm{m}^{2}$ ( $3 \mathrm{stems} / \mathrm{ft}^{2}$ ) was obtained. This is lower than expected, but prairie grasses tend to put their first energy into developing root mass, with aboveground foliation difficult to detect (Stock 1999 ${ }^{1}$ ). The area was seeded in late September 1999, which is earlier than recommended for dormant planting and too late for fall germination. Despite this risk, the site was seeded because of the important cultural resource associated with it and the associated consequences of not making every effort to prevent erosion. When little evidence of germination was apparent by mid-July 2000, a decision was again made that the probability of a failed seeding was too much risk to take, and on July 26, the area was re-hydroseeded. The same mixture of grasses was used, with no mulch, tackifier, or fertilizer. Mulch and tackifier were not used since the seeds were hydroseeded over the top of the existing Excelsior ${ }^{\circledR}$ blanket and the seeds were presumed able to penetrate the fabric and be in contact with the underlying soil. No additional fertilizer was added because remnant fertilizer was believed to remain from the fall 1999 seeding. An irrigation system was installed on the bank and was initially operated at least every 2 days, depending on the weather. A September 6, 2000 inspection revealed that germination had occurred, but density was not estimated.

In a few areas, the Excelsior ${ }^{\circledR}$ blanket has separated, but the exposed bank does not appear to be eroding. To test the benefit of the erosion control blanket, a small area at the north end of the fill was not covered with an Excelsior ${ }^{\circledR}$ blanket. No major signs of erosion are evident where the blanket was absent. The quadrat count did show a higher stem count without the blanket $\left(64 \mathrm{stems} / \mathrm{m}^{2}\right.$ or $\left.6 \mathrm{stems} / \mathrm{ft}^{2}\right)$ than with an Excelsior ${ }^{\circledR}$ blanket $\left(26 \mathrm{stems} / \mathrm{m}^{2}\right.$ or $\left.2.4 \mathrm{stems} / \mathrm{ft}^{2}\right)$. This increase is nonconclusive for several reasons, however: (a) the proximity of native grasses on the northern end that may have provided seed, (b) the more gradual slope, and (c) less direct

\footnotetext{
${ }^{1}$ Stock, D. (1999). "Planting and maintaining prairie grasses," Land and Water (Jul/Aug), 3739.
} 
sunlight due to the slightly northern orientation of this section of bank. The Excelsior ${ }^{\circledR}$ blanket remains suspect in some areas, however, because it is greater than $1.3 \mathrm{~cm}(1 / 2 \mathrm{in}$.) thick, which may not allow enough sunlight to reach the seeds. ${ }^{1}$

Zone 3 Branchbox Performance. The branchbox breakwater is providing limited habitat for emergent plants (Figure 14). The habitat is limited because Wisconsin laws prohibit most structures from being more than a few feet away from the shore. The Wisconsin Department of Natural Resources did, however, allow this structure for demonstration purposes, but only allowed it to extend $4.5 \mathrm{~m}(15 \mathrm{ft})$ from the shore. This is still short of the more typical placements of $10 \mathrm{~m}(33 \mathrm{ft})$ or more.

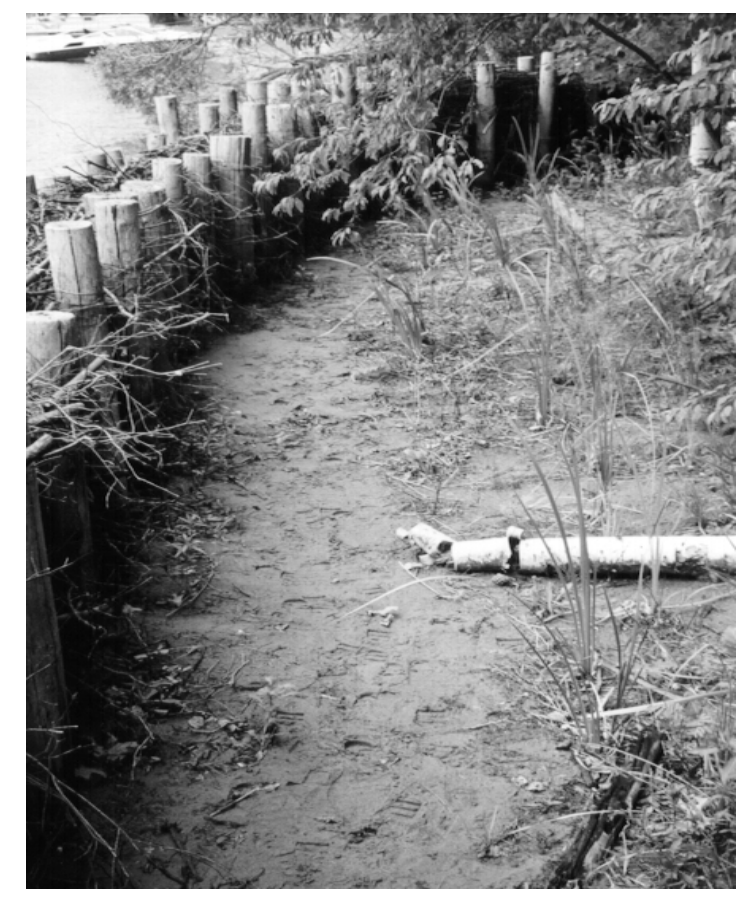

Figure 14. Area behind branchbox breakwater

It appears that the area between the branchbox and shore may have suffered from either or both of two effects created by the branchbox's proximity to the bank. First, the protected area is shaded by existing trees on the steep bank for half of the day, then is shaded by the branchbox breakwater for much of the remainder of the day. This lack of sunlight may be responsible for an observed $0.76-\mathrm{m}-(2-1 / 2-\mathrm{ft}-)$ wide area directly behind the branchbox that is unvegetated (Figure 14). Second, sand has deposited behind the branchbox to a height approximately 6 in. higher than directly in front of the branchbox. This sand appeared to be enough to cover small plants as they began to grow. Between this 0.76-m- (2-1/2-ft-) wide void and the original bank, however, there is vegetation. Quadrats were used twice to assess the vegetation of the entire area behind the branchbox breakwater, once on May 17, 2000 and again on July 7, 2000. The entire area was covered with 28 quadrats or partial quadrats. Numbers of Juncus effusus, Scirpus spp.,

${ }^{1}$ Personal Communication. August 30, 2000. John Wade, General Manager, Taylor Creek Nursery and Applied Ecological Services, Brodhead, WI. 
Iris versicolor, Acorus calamus, grasses, dicots, other herbaceous plants, and the percentage of the area covered by leaf cover and bare ground were recorded. To verify the visual observations, the quadrats adjacent to the branchbox were compared to the quadrats away from the structure. As expected, the average percent of bare ground is higher for the adjacent quadrats (54.3 percent in May and 43 percent in July) compared to the non-adjacent quadrats, with 35 percent in May and 30 percent in July.

Of the planted species, Iris versicolor and Acorus calamus had the highest survival percentages when measured on July 7, 2000 (135 percent and 105 percent, respectively) indicating they have already regenerated. Scirpus spp. have not faired as well, having a combined survival percentage on July 7, 2000 of 18 percent. Of the 60 Juncus that were planted, none survived (Figure 15).

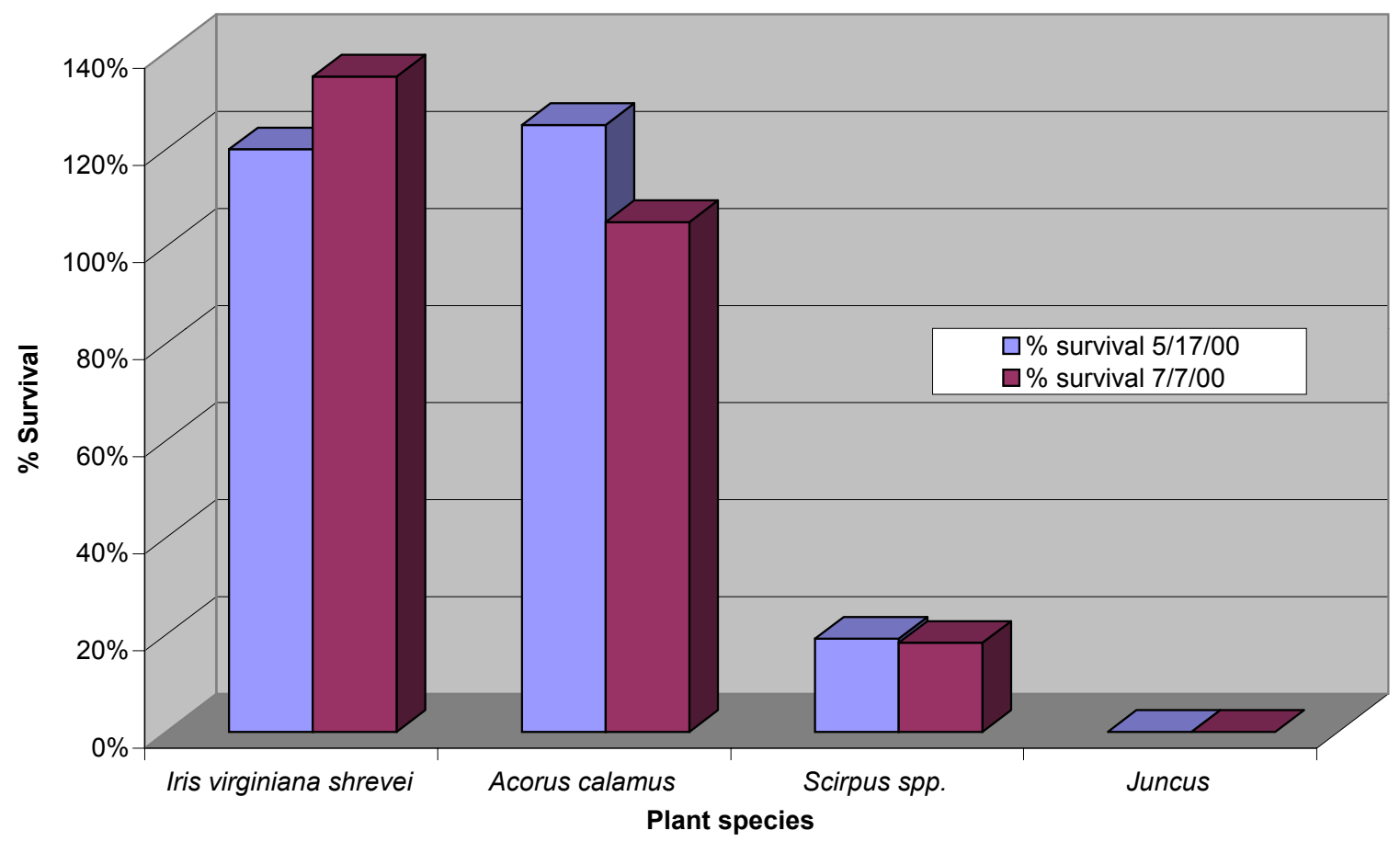

Figure 15. Survival of plants behind the branchbox breakwater

Zone 3 A-Jacks ${ }^{\circledR}$ Performance. Due to the heavy vegetation, the A-Jacks ${ }^{\circledR}$ are barely visible from the water. Although the total stem count has decreased (359 stems on July 7, 2000 down from 391 stems on May 16, 2000), the percent area covered is increasing based on visual comparison of photos (Figures 16 and 17). The stem count may have decreased for several possible reasons. First, the water level of the reservoir was within $3 \mathrm{ft}$ of full by the middle of April, which provided the plants with adequate moisture producing the initial surge of growth indicated by the high stem count for May. Second, from the end of June through early August the water level was within $1 \mathrm{ft}$ of full and some of the individuals may have succumbed to drowning and/or wave action causing abrasion from the A-Jacks ${ }^{\circledR}$, lowering the overall stem count. Third, competition for light and nutrients between individual plants may have been a source of mortality. 


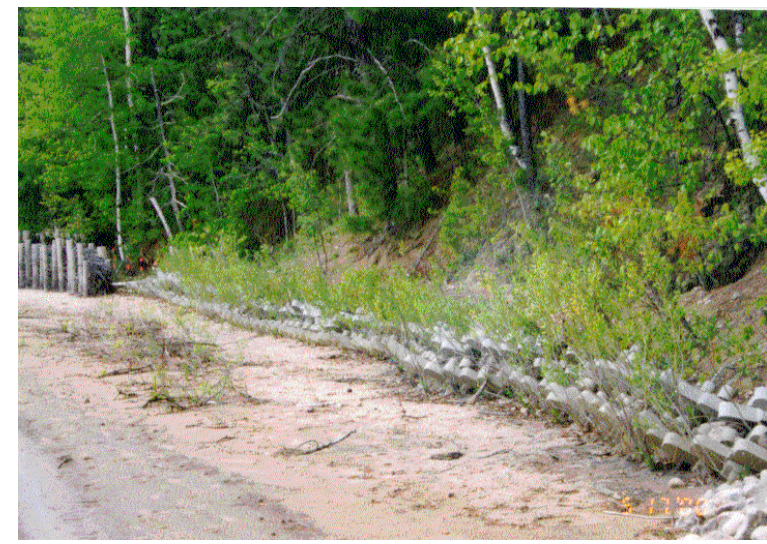

Figure 16. A-Jacks $®$ willow coverage, May 2000

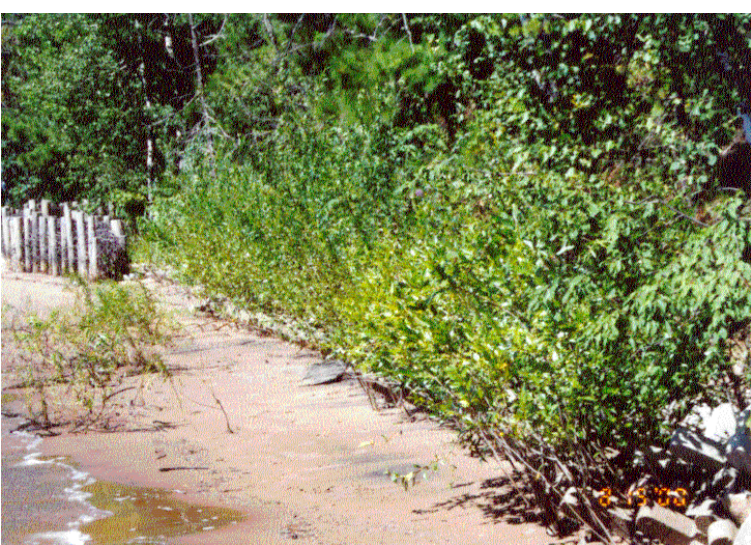

Figure 17. A-Jacks ${ }^{\circledR}$ willow coverage, July 2000

Costs. Costs of materials and labor were calculated separately because material costs are relatively uniform, whereas labor costs could vary considerably depending on the source. The man-hours could also vary depending on the equipment available, but generally the installations in the project did not allow a lot of leeway in where equipment could or could not be used. Equipment costs are not included because of the wide cost variation depending on a user's access to equipment or choice of equipment to do the job. Material and man-hour investments are summarized in Table 1 below.

\section{Table 1 \\ Cost of Utilized Shoreline Stabilization Treatments}

\begin{tabular}{|l|l|l|l||}
\hline \hline Method of Stabilization & Linear Distance, feet & Material Cost, linear ft & Man hours, linear ft \\
\hline \hline $\begin{array}{l}\text { Fiber roll toe with wave } \\
\text { deflectors }\end{array}$ & 150 & $\$ 15$ & $1.3 \mathrm{hr}$ \\
\cline { 1 - 3 } $\begin{array}{l}\text { Fiber roll toe without wave } \\
\text { deflectors }\end{array}$ & $\$ 10$ & $0.6 \mathrm{hr}$ \\
\hline Rock toe-fix away from mound & 350 & $\$ 38$ & $2.9 \mathrm{hr}$ \\
\hline Rock toe - mound fix & 100 & $\$ 150$ & $11.8 \mathrm{hr}$ \\
\hline A-Jacks toe & 100 & $\$ 25$ & $1.2 \mathrm{hr}$ \\
\hline Branchbox breakwater & 50 & $\$ 7$ & $2.5 \mathrm{hr}$ \\
\hline \hline 1 Cost does not include use of WVIC equipment. & & \\
\hline
\end{tabular}

LESSONS LEARNED: The following observations resulted from this case study:

- Wave deflectors must be installed differently in a reservoir with fluctuating water levels. Possibly if the crosspieces were eliminated from the design, the larger trees could be anchored more securely.

- Fiber rolls can be easily vegetated using willow cuttings. There does not appear to be any advantage to using rooted stock instead of dormant, unrooted cuttings. Inserting herbaceous plants into the fiber roll is difficult and was not very successful at this particular site. 
- It is much more cost-effective to limit erosion control at high eroding banks to the toe without filling to the top (see cost comparisons above of "Rock Toe - Fix Away from Mound" vs "Rock Toe - Mound Fix").

- Steep banks can be protected through bioengineering techniques or hybrid techniques; protection methods are not limited to retaining walls or similar structures.

- It was more costly and time-consuming to pre-grow the plant materials for brush layers than to harvest local dormant material, and there was no apparent advantage in survivability of pregrown over dormant cuttings. However, dormant cuttings must be installed soon after harvesting, since they are sensitive to storage conditions.

- A-Jacks ${ }^{\circledR}$ can be easily and effectively vegetated by jetting dormant cuttings into and around them.

- A branchbox breakwater effectively dissipates wave energy, thereby allowing wetland plants to establish.

APPLICABILITY AND LIMITATIONS: Each method of bank stabilization must be evaluated for its applicability. All of the methods have been in place for two open-water seasons and one winter. Ice has had negligible impact on the structures.

Fiber roll toes work very well in a low-energy area with lower banks. They can be successfully tiered to three high to match the original configuration of the bank and can be installed without the use of heavy equipment. They are easily vegetated and provide wildlife habitat. Comparatively, they are the least labor-intensive to install. Due to the rapid failure of the wave deflectors, very little information was gathered on the benefits of such a structure. They may have played a critical role in attenuating wave action while the vegetation became established in this zone. With modifications, a wave deflector may work to provide protection for the establishment or reestablishment of vegetation.

The rock toe is a proven method of stabilization on reservoir shorelines in high-energy situations. Access to the bottom of the bank with heavy equipment is necessary; therefore, construction must take place in winter or when the reservoir is drawn down. Costs can be cut considerably by reducing the amount of rock used and modifying bank-top treatments.

Constructing a vegetated geogrid as the top bank treatment is expensive and time-consuming; however, the outcome provides an immediate fix. It is also visually aesthetic and provides habitat for a variety of animals. This particular design was utilized since many limitations were placed on the dimensions of the structure. The area needed to be filled without damaging the bank, and the rock toe could not be extended out far enough to produce a stable slope.

A-Jacks ${ }^{\circledR}$ successfully provide toe protection without any disturbance to the bank. They can be installed without heavy equipment and are easy to vegetate with dormant cuttings. 
Although the branchbox breakwater had limited success in this project, the structure could be well-utilized under different circumstances. In states other than Wisconsin, the breakwater would be located farther from the shoreline as designed. This would protect a much larger area for vegetation establishment.

ACKNOWLEDGEMENTS: This research was developed under the Water Quality Research Program managed by the U.S. Army Engineer Research and Development Center (ERDC), Waterways Experiment Station, Vicksburg, Mississippi. The study was conducted in cooperation with the Wisconsin Valley Improvement Company (WVIC), Wausau, Wisconsin. Thanks are expressed to Mr. Jason Kuiken, a student at the University of Wisconsin, Stevens Point, who was working for the WVIC during the summer and who conducted the field vegetation assessments and assisted with the writing of this report. Appreciation is expressed to Dr. Wilma Mitchell, Wildlife Biologist, and Mr. Jerry Miller, Civil Engineer, both of the Ecological Resources Branch, Environmental Laboratory, ERDC, who reviewed the report.

POINTS OF CONTACT: This technical note was written by Ms. Cathy J. Wendt, Environmental Specialist, Wisconsin Valley Improvement Company, and Mr. Hollis H. Allen, Ecologist, U.S. Army Engineer and Research Development Center, Waterways Experiment Station.

For additional information, contact the managers of the Water Quality Research Program, Dr. John W. Barko (601-634-3654,John.W.Barko@erdc.usace.army.mil), or Mr. Robert C. Gunkel, Jr. (601-634-3722, Robert.C.Gunkel@erdc.usace.army.mil). This technical note should be cited as follows:

Wendt, C. J., and Allen, H. H. (2001). "Archaeological site and reservoir shoreline stabilization using wetland plants and bioengineering, Rice Reservoir, Wisconsin," Water Quality Technical Notes Collection (ERDC WQTN-CS-02), U.S. Army Engineer Research and Development Center, Vicksburg, MS. www.wes.army.mil/el/elpubs/wqtncont.html

NOTE: The contents of this technical note are not to be used for advertising, publication, or promotional purposes. Citation of trade names does not constitute an official endorsement or approval of the use of such products. 